\title{
Hemophilic Siblings with Chronic Hepatitis C: Familial Aggregation of Spontaneous and Treatment-Related Viral Clearance
}

\author{
Michael W. Fried, M.D. ${ }^{1}$, Barbara L. Kroner, Ph.D. ${ }^{2}$, Liliana R. Preiss, M.S. ${ }^{2}$, Kirk \\ Wilhelmsen, M.D., Ph.D. ${ }^{3}$, James J. Goedert, M.D. ${ }^{4}$, and the Multicenter Hemophilia Cohort \\ Study \\ ${ }^{1}$ Division of Gastroenterology and Hepatology, University of North Carolina at Chapel Hill, Chapel \\ Hill, NC \\ ${ }^{2}$ Research Triangle Institute, Rockville, MD \\ ${ }^{3}$ Human Genetics and Neurology, University of North Carolina at Chapel Hill, Chapel Hill, NC \\ ${ }^{4}$ Viral Epidemiology Branch, National Cancer Institute, Rockville, MD
}

\begin{abstract}
Introduction-Hemophilic siblings provide a unique population to explore the natural history of chronic hepatitis $\mathrm{C}$.

Methods-From 3,993 hemophilic patients with hepatitis C, 257 sibling pairs, in which both members had evidence of hepatitis $\mathrm{C}$ infection, were studied to evaluate the genetic contribution to spontaneous and treatment-induced clearance of hepatitis $\mathrm{C}$ infection and the progression of liver disease. Familial aggregation was assessed by comparing observed probabilities of concordance for these disease characteristics within sibling pairs to those expected for randomly paired hemophilic subjects. Additional measures of familial aggregation, heritability and sibling relative risk, were also calculated.

Results-Among HIV-negative subjects, concordance for spontaneous viral clearance was twofold higher in siblings compared to randomly paired subjects ( $8.8 \%$ vs $4.3 \%, \mathrm{p}=0.04)$. Similarly, the concordance rate for treatment-related viral clearance was over twice that among sibling pairs than among randomly paired hemophiliacs $(31.3 \%$ vs $13.3 \%, \mathrm{p}=\mathrm{ns})$. Heritability estimates for spontaneous and treatment-induced viral clearance were $0.24 \pm 0.14(\mathrm{p}=0.04)$ and $0.43 \pm 0.42$ $(\mathrm{p}=0.10)$, respectively. The sibling relative risks for these respective characteristics were 1.6 and 1.7. Concordance for advanced liver disease was higher among siblings, but did not reach statistical significance $(4.0 \%$ vs $2.3 \%, p=n s)$. The heritability estimate was $0.29 \pm 0.13(p=0.02)$.
\end{abstract}

Conclusions-Concordance rates and heritability estimates for spontaneous and treatmentrelated viral clearance indicate that genetic factors have a modest influence on the outcome of hepatitis $\mathrm{C}$, although shared environmental factors cannot be excluded. Investigations to map

Copyright (c) 2006 The American Gastroenterological Association. All rights reserved.

Address for correspondence: Michael W. Fried, M.D., University of North Carolina, CB\# 7584, Room 8015 Burnett-Womack Bldg. Chapel Hill, NC 27599, Phone: 919-966-2516, FAX: 919:966-1700, mfried@ med.unc.edu.

Publisher's Disclaimer: This is a PDF file of an unedited manuscript that has been accepted for publication. As a service to our customers we are providing this early version of the manuscript. The manuscript will undergo copyediting, typesetting, and review of the resulting proof before it is published in its final citable form. Please note that during the production process errors may be discovered which could affect the content, and all legal disclaimers that apply to the journal pertain. 
candidate disease-susceptibility genes associated with these characteristics must be approached with caution.

\section{Introduction}

Hepatitis $\mathrm{C}$ virus (HCV) is unique among hepatotropic viruses for its propensity to cause chronic infection and for the variable outcome of the disease. Population-based studies in the United States indicate that approximately $75 \%$ of patients remain chronically infected with hepatitis C (1). In contrast, up to $50 \%$ of patients have been reported to spontaneously resolve hepatitis $\mathrm{C}$ infection when exposure occurred in children undergoing cardiac surgery or cancer chemotherapy, in young women after a common-source outbreak of contaminated anti-D immunoglobulin, or in healthcare workers after needlestick exposures (2-4).

The clinical spectrum of hepatitis $\mathrm{C}$ is also variable, ranging from asymptomatic, mild infection to cirrhosis, portal hypertension and liver failure (5). Attempts to define the natural history of hepatitis $\mathrm{C}$ have yielded conflicting results and indicate that the outcome is neither uniformly fatal nor predictable. Fewer than $10 \%$ of European women infected with hepatitis $\mathrm{C}$ from anti-D immunoglobulin, progressed to cirrhosis, and the majority had only mild chronic hepatitis, after two decades of observation $(2,4,6)$. Similarly, patients with hepatitis $\mathrm{C}$ viremia may have persistently normal ALT activities during prolonged monitoring with minimal histologic changes $(7,8)$. In an early study of transfusion associated non-A, non-B hepatitis, there was a small but significant increase of liver related mortality in hepatitis patients over an 18-year follow-up from the time of transfusion (9). In contrast, patients with transfusion associated hepatitis $\mathrm{C}$ followed at a tertiary referral center had a high incidence of cirrhosis and death from liver failure or hepatocellular carcinoma, although these results were undoubtedly biased by the nature of the referral population. Nevertheless, end-stage liver disease due to hepatitis $\mathrm{C}$ is the most common indication for liver transplantation in the United States $(10,11)$.

The factors that contribute to the varied clinical course of this disease are largely unknown. Epidemiologic studies have suggested that the likelihood of spontaneous viral clearance is associated with age at infection, gender, race, and severe acute icteric illness (12-15). Alcohol consumption greater than 50 grams per day, older age at acquisition, male gender, and co-infection with human immunodeficiency virus (HIV) were independent risk factors associated with more rapid progression of fibrosis in patients with hepatitis $C(13,16)$. Interestingly, viral factors, such as hepatitis C genotype and level of HCV RNA have not been consistently implicated as factors associated with viral clearance nor with increased fibrosis (17-19).

While this information has been valuable in helping clinicians to stratify the global risk of chronic infection and disease progression for their patients, these epidemiologic factors are unlikely to be solely responsible for clinical outcomes. Complex interactions must exist with other host factors, including the immune response and host genetic variables that mediate expression of antiviral response, but are far more difficult to study.

Increasing emphasis is being placed on the investigation of host genetic factors that may be associated with the natural history, clinical manifestations, or response to therapy of chronic hepatitis $\mathrm{C}$ and other liver diseases. Recent data suggests that polymorphisms of genes associated with hepatic fibrogenesis, oxidant stress, immune response, or antiviral defense mechanisms may influence the course of chronic liver disease (20-26). However, these studies are often limited by a small sample size from tertiary centers that may not represent individuals spanning the entire spectrum of disease (27). In addition, these studies have focused on only single genes, some with polymorphisms of uncertain functional 
significance, and usually did not attempt to evaluate gene-environment interactions that could affect interpretation of the results (27). Furthermore reporting bias for nominally significant results, inadequate correction for multiple comparisons (28) or realistic assessment of the prior probability for association(29) and failure to consider population stratification (30-32) may make the available association analysis literature suspect.

The aim of the present study was to assess the relative contributions of genetic factors in the evolution of hepatitis $\mathrm{C}$ disease in a unique group of hemophilic siblings. Individuals with inherited coagulation disorders (hemophilia and von Willebrand's disease, referred to herein as hemophilia) who received unsterilized blood products have a prevalence of hepatitis $\mathrm{C}$ infection (70-90\%) that is unsurpassed by any other defined risk group (14, 18, 33-35). Hemophilic siblings are an attractive population to study in relation to the natural history of hepatitis $C$ because: 1 ) They are almost exclusively males; 2 ) Siblings are relatively close in age and duration of follow-up; 3) The mode of HCV acquisition is identical; 4) The date of acquisition can be estimated based upon their factor replacement history; 5) The age of HCV acquisition is similar; and 6) Siblings share varying degrees of genetic material. The following analyses have important implications for mapping candidate disease modifying genes related to viral clearance and progression of liver disease in patients with chronic hepatitis $\mathrm{C}$.

\section{Methods}

\section{Subjects}

Subjects for this study were derived from participants in two large, consecutive studies of patients with hemophilia that were exposed to unsterilized blood products. The first Multicenter Hemophilia Cohort Study (MHCS-I) $(36,37)$, funded by the National Cancer Institute, was initiated in 1983 and maintained follow-up for enrollees through 1999. MHCS-I included all hemophiliacs registered at 17 participating treatment centers in five countries. The second Multicenter Hemophilia Cohort Study (MHCS-II), initiated in 2001, included hemophiliacs from 54 participating treatment centers (13 centers from MHCS-I) in eight countries (38). Eligibility criteria included at least 13 years of age at the time of enrollment and previously confirmed infection with HCV.

From the combined MHCS-I and II HCV-infected cohorts (n=3,993), 257 families that had two or more infected whole siblings, where both members were positive for anti-HCV, were identified and served as the initial study group of interest. In 24 families with more than two eligible siblings, two were randomly selected to form a pair for the subsequent analyses. Each sibling pair was assigned a unique numeric identifier. All subjects (or their legal guardians) provided written informed consent prior to blood collection and examination under a protocol approved by all participating institutions.

\section{Definitions}

Date of infection-The date of infection was estimated for all subjects based on their hemophilia type and severity and factor replacement histories, as has been previously described (15). For the current study, the date of infection was imputed as the midpoint between the exposure interval with the first use of factor concentrate defining the upper limit (MATLAB, MathWorks, Natick, MA). Dates of infection for individuals with missing factor replacement histories were estimated as the median date of infection for the group of individuals with known histories, born within 3 years, and having the same hemophilia severity. 
HCV Clearance-HCV clearance was defined as undetectable HCV RNA levels (bDNA (Bayer), Amplicor (Roche) and/or TaqMan PCR) in the most recent sample tested. Subjects meeting this definition were further classified as spontaneously clearing their infection if they had never been treated with interferon-based therapy. HCV RNA clearance was considered to be treatment-induced for those subjects who had received any interferon-based therapy either alone or in combination with ribavirin.

Advanced liver disease: Participants were considered to have advanced liver disease (ADV) if they met at least one of the following criteria:

1. Liver biopsy demonstrating stage III or stage IV fibrosis or the presence of cirrhosis as a descriptor

2. The presence of ascites, or esophageal varices.

3. Liver disease as a cause of death on the death certificate

4. Primary liver cancer

5. The presence of at least 2 of the following conditions: hepatic encephalopathy, albumin $<=3.0 \mathrm{~g} / \mathrm{dl}$, or prolonged prothrombin time $>15$ seconds

6. One of the conditions in \#5 above plus hyperbilirubinemia $\geq 2.5 \mathrm{mg} / \mathrm{dl}$, or platelet count $\leq 120,000$ cells $/ \mathrm{mm}^{3}$; or

7. Last two platelet counts $<100,000$ cells $/ \mathrm{mm}^{3}$

The date of ADV was considered to be the date of the earliest diagnosed event in categories 1-5 above, and the date of the second abnormal laboratory result in categories 6-7

\section{Statistical analysis}

The expected and unadjusted probability of two randomly selected individuals having a concordant diagnosis of spontaneous or treatment-induced HCV clearance or ADV was calculated as the square of the population frequency for those at risk for the two events. Similarly, the probabilities of two individuals being discordant for disease or concordant for the absence of disease were also calculated. The concordance and discordance frequencies of the random pairs were compared with those of the sibling pairs using the Breslow-Day test for homogeneity comparing two odds ratios. Because of its strong and potentially modifying effect, analyses were stratified by HIV status.

The individual probabilities (cumulative hazards) of being diagnosed with advanced liver disease after $\mathrm{HCV}$ seroconversion was determined for each sibling from proportional hazards models of all subjects with non-missing data. Subjects that had spontaneously cleared their HCV infections were not considered at risk for HCV-related liver disease and excluded from this analysis. Cumulative hazards for 2238 subjects, including 125 complete sibling pairs, were adjusted for age at HCV infection, birth year, HIV status, and HBV chronicity by including these variables in the models.

The cumulative hazard for each sibling was subtracted from his disease indicator flag ( 1 for $\mathrm{ADV}, 0$ for no ADV), resulting in a residual risk that represented the observed minus the expected probability for advanced liver disease (39).

Concordance of the residual risks between siblings in the same family was evaluated by analysis of variance with the residual risk as the dependent variable and the pair number as the independent variable. The intraclass correlation coefficient (ICC), or the proportion of variation that occurred among the pairs, was calculated from the sum of the mean squares within and between sibling pairs (39). If genetics were the sole factor associated with $\mathrm{HCV}$ 
clearance or disease progression and all siblings shared the expected gene, the expected ICC $=1$. The null hypothesis of ICC $=0$ was tested using the F statistic.

\section{Measures of familial aggregation}

Heritability $\left(\mathrm{h}^{2}\right)$ of a trait is the proportion of total variance of a phenotype that is genetic (40). It is customary to use twin data to estimate the proportion of phenotypic variance that is due to genetic, shared and nonshared environmental factors. In most twin analysis there is assumed to be an additive mode of inheritance. Family studies with a variety of relationship types are used to determine the most probable mode of inheritance. In this data set only sibling data are available such that it is impossible to have insight into the mode of inheritance or to disentangle shared environmental and genetic contributions to susceptibility. In these analyses we assume that there are no shared environmental effects. Thus, $\mathrm{h}^{2}$ represent an upper limit of the genetic contribution.

$\mathrm{h}^{2}$ estimates were calculated for spontaneous and treatment-induced viral clearance and for the presence of advanced liver disease using the SOLAR, version 2.1.4 (41). The phenotype for an individual is assumed to be equal to the sum of the population mean, products of covariate values for the individual and covariate regression coefficients, and the deviation from the mean due to genetic and residual effects (usually called the environmental effects). It is assumed that the deviations from the mean due to genetic and environmental effects are not correlated and are normally distributed with mean 0 and variance of $\sigma_{\mathrm{g}}^{2}$ and $\sigma_{\mathrm{e}}^{2}$. Assuming the simplest model, it follows that covariance for relative pairs is equal to 2 times the kinship coefficient times $\sigma_{\mathrm{g}}^{2}$ plus $\sigma_{\mathrm{e}}^{2}$ and the variance due to covariates. $\mathrm{h}^{2}$ is defined as $\sigma_{\mathrm{g}}^{2} /\left(\sigma_{\mathrm{g}}^{2}+\sigma_{\mathrm{e}}^{2}\right)$. In this model the estimates of $\mathrm{h}^{2}$ can be increased when covariance for relative pairs due to shared environmental effects are correlated with he kinship coefficient.

\section{Sibling relative risk}

The sibling relative risk, $\lambda_{\mathrm{s}}$, is another measure of familial aggregation that is commonly used to assess the feasibility of genetics studies (42). $\lambda_{\mathrm{s}}$, (the risk of a sibling of an affected individual divided by the population risk) is commonly used as an upper bound for the genotypic relative risk which together with disease associated allele frequency determines the sample size required to detect a significant association. We assumed that the risk of an affected individual sibling is equal to the number of concordant affected sibling pairs divided by the number of concordant affected sibling pairs plus half of the discordant sib pairs. The population risk was estimated from population of sporadic individuals. Most traits that are considered tractable for genetic analysis have $\lambda_{\mathrm{s}}$ greater than 2.3 and preferably greater than 10 .

\section{Results}

The demographic and descriptive data of the hemophilic population and the sibling subset is provided in table 1 . Three-quarters of the total study population had hemophilia A and twothirds were characterized as severe hemophilia. Forty-six percent were infected with HIV. These characteristics were more frequent in the subset of 514 siblings $(\mathrm{p} \leq 0.04)$ which was due to targeted recruitment of HIV-infected siblings for MHCS-1 (39). The median age at the time of HCV infection for the total population and the subgroup of siblings was 7.5 years and the median duration of HCV infection was 25 years. The prevalence of chronic hepatitis B carriers (HBsAg) did not differ significantly (6.6\% vs 7.4\%, respectively). More than half of the hemophilic subjects did not drink any alcohol and an additional $38 \%$ drank only 1 drink per week. Thus, $89 \%$ of hemophilics drank little or no alcohol, which was similar between the total hemophilic population and siblings. 


\section{Familial aggregation for spontaneous HCV clearance in the sibling pairs}

Spontaneous clearance of HCV infection occurred in 562 (16.4\%) hemophiliacs. Of these, 365 were HIV-negative and 197 HIV-positive. Among siblings, spontaneous clearance was seen in $15.6 \%$ ( $\mathrm{p}=\mathrm{ns})$. The probability of two randomly paired individuals having spontaneously cleared their infection was $2.7 \%$ in the total population at risk. In comparison, there were 9 sibling pairs (4.0\%) concordant for spontaneous clearance from the 228 sibling pairs at risk ( $\mathrm{p}=0.07)$ (Table 2). Among the HIV-negative subjects, the expected concordance for spontaneous clearance between two randomly paired individuals was $4.3 \%$. Of the $80 \mathrm{HIV}$ negative sibling pairs, 7 were concordant for spontaneous clearance $(8.8 \%, \mathrm{p}$ $=0.04)($ Table 2$)$.

$\mathrm{h}^{2}$ for spontaneous viral clearance was $0.25 \pm 0.14\left(\mathrm{p}=0.04\right.$ that $\mathrm{h}^{2}$ significantly different than zero; see table 3 ). The sibling relative risk, $\lambda_{\mathrm{s}}$, was estimated to be 1.6.

\section{Familial aggregation for treatment-related HCV clearance in the sibling pairs}

Six-hundred sixty-four (17.6\%) hemophilic subjects had received treatment for chronic hepatitis $\mathrm{C}$ with an interferon-based regimen. Twenty-seven percent of these were treated with interferon monotherapy while $73 \%$ had received combination therapy with interferon or peginterferon and ribavirin. Among the treated subjects, $36 \%$ demonstrated sustained virological response. Therefore, the probability for two randomly paired individuals having virological concordance for sustained virological response was $13.3 \%$. Remarkably, among 16 sibling pairs, both of whom had received therapy for chronic hepatitis $\mathrm{C}$, five pairs (31.3\%) were concordant for sustained viral clearance. This did not reach statistical significance (Table 2). In three additional pairs, neither cleared HCV RNA, while in 8 pairs one sib cleared while the other remained infected.

$\mathrm{h}^{2}$ for treatment-related viral clearance was $0.43 \pm 0.42\left(\mathrm{p}=0.10\right.$ for $\mathrm{h}^{2}$ being different than 0$)$ while the sibling relative risk was 1.7 (Table 3 ). These measures of familial aggregation are imprecise because of the sample size.

\section{Familial aggregation for liver disease in the sibling pairs}

In a subset 2238 subjects with persistent hepatitis $\mathrm{C}$ and complete data, advanced liver disease developed in $15.1 \%$. The clinical characteristics defining advanced liver disease are shown in table 4 . The probability of two randomly paired individuals having ADV was $2.3 \%$. In comparison, there were 5 sibling pairs (4\%) concordant for ADV out of the 125 total pairs at risk $(\mathrm{p}=\mathrm{ns})$, suggesting a weak familial component to advanced liver disease. From these data, heritability for advanced liver disease was $0.29 \pm 0.13\left(\mathrm{p}=0.02\right.$ for $\mathrm{h}^{2}$ being different than 0 ) while the sibling relative risk was estimated to be 2.1 (Table 3 ).

We next examined this familial association by analyzing the time from HCV infection to ADV in a proportional hazards model that included age at HCV infection ( $\mathrm{p}<.0001), \mathrm{HIV}$ status ( $\mathrm{p}<.0001)$, HBsAg carriage $(\mathrm{p}=.05)$, and birth year $(\mathrm{p}<.0001)$. Alcohol usage was not a significant predictor of ADV, and therefore, not included in the model. After adjusting for other factors that were significantly associated with progression to ADV, there was no concordance for disease within the sibling pairs $(\mathrm{ICC}=0.0)$. When we included only those 1764 subjects that had been infected with HCV for at least 20 years, the ICC in the 96 sibling pairs was 0.09 .

\section{Discussion}

The present study evaluated a unique cohort of hemophilic siblings to ascertain the relative influence of familial relationship on HCV viral clearance and on progression to advanced 
liver disease. Several novel features distinguish this study from others that have tried to address questions regarding the natural history of hepatitis $\mathrm{C}$ infection. The relatedness of the sibling pairs, the ability to reliably estimate the duration of HCV infection, and the homogeneity of the cohort related to gender, age at infection, alcohol intake, and mode of acquisition provide a rare opportunity to evaluate the influence of host genetics on hepatitis C infection.

Spontaneous resolution of hepatitis C infection occurred in approximately $17 \%$ of all subjects in this study, with a substantially lower rate of viral clearance among those coinfected with HIV. These rates of viral clearance are consistent with other reports in nonhemophilic populations (1), although somewhat less than reported in children and young women infected through contaminated blood products $(4,43)$. In the hemophilia cohort, repeatedly exposed to unsterilized blood products, it is possible that single episodes of spontaneous viral clearance were overshadowed by reinfection during subsequent exposures, as has been demonstrated in thalassemic patients who developed repeated episodes of acute hepatitis $\mathrm{C}$ following multiple exposures (44). Thus, the hemophilic subjects in the present study represent those with durable viral clearance suggesting a robust antiviral response, the nature of which is worthy of further investigation.

The present study found that concordance for spontaneous viral clearance was significantly greater among sibling pairs than among randomly assigned pairs of hemophilics. This concordance in viral clearance supports the hypothesis that host antiviral response is influenced by genetic factors shared within the sibships. This finding is consistent with studies that have found an association between a variety of single gene polymorphisms involved in the immune response and HCV viral clearance (45-48). Thus, genes encoding an inhibitory natural killer (NK) cell receptor and IL-10 have been associated with viral clearance while polymorphisms of HLA-Cw*04 and tumor necrosis factor $\alpha$ have been implicated in HCV viral persistence (45-48).

Remarkably, we have also demonstrated that the observed concordance within sibships for viral clearance as a result of antiviral therapy is over twice what would be expected from randomly paired, unrelated subjects with hemophilia and hepatitis $C$. However, due to the small sample size of treated sib pairs, this did not reach statistical significance. Nevertheless, this information provides additional support for a relationship between host genetics and $\mathrm{HCV}$ viral clearance and is consistent with several recent reports that evaluated gene expression and gene polymorphisms in individuals with and without sustained virological response to interferon-based regimens (49-54). Using microarrays in hepatic tissue, Chen and colleagues identified a number of interferon-sensitive genes that correlated with response to antiviral therapy (50). Similarly, among black and white patients with chronic hepatitis $\mathrm{C}$ treated with interferon, different patterns of expression of interferon-stimulated genes, such as 2,5-OAS, MxA, and PKR, were identified between individuals of African and European ancestry, suggesting potential mechanisms for diminished response to antiviral therapy seen in African American patients (55). The vast majority of subjects in the present study were of European ancestry.

Approximately $15 \%$ of hemophilics infected with hepatitis $\mathrm{C}$ developed advanced liver disease over a prolonged period of observation, a prevalence rate that is less than those reported in studies of non-hemophilics. This relatively low rate of disease progression is unexpected, particularly since many subjects were co-infected with HIV, a combination that has been repeatedly demonstrated to increase the likelihood of disease progression. Goedert et al (14) analyzed the incidence of end-stage liver disease in the first Multicenter Hemophilia Cohort Study and found a similar rate of end-stage liver disease (14\%) for those co-infected with HIV but only $2.6 \%$ for those without HIV infection. 
The criteria to define advanced liver disease in the present study utilized stringent clinical and/or laboratory endpoints. Although liver biopsies can be safely performed with appropriate precautions in individuals with inherited disorders of coagulation (56), liver biopsies were infrequently performed. Therefore, it is possible that the extent of cirrhosis, in those without clinical or laboratory evidence of advanced disease, was underestimated. Nevertheless, we do not expect that this was a significant confounder in our analyses, particularly because the same clinical criteria were applied uniformly across the sib and nonsib groups. This cohort also had a low frequency of alcohol ingestion, another co-factor believed to accelerate $\mathrm{HCV}$ disease progression. The vast majority of participants (88\%) reported drinking one or less than one alcoholic beverage per day.

It is assumed that complex traits, such as HCV viral clearance and development of cirrhosis, occur as the result of the interaction between genetic and environmental factors. Indeed, a recent study that evaluated non-genetic factors in a cohort of hemophilic subjects has suggested that coinfection with hepatitis $\mathrm{B}$, recent year at infection, and younger age at infection were associated with spontaneous viral clearance (15). In that study, no attempt was made to evaluate potential genetic factors. The present study, however, utilized an expanded cohort of these hemophilic subjects and specifically sought to evaluate the genetic influence on viral clearance and disease progression by exploring these phenotypes within sibling pairs. The results of these two studies, therefore, are complementary. The current results, in aggregate, indicate that these outcomes (viral clearance and disease progression) are also influenced by genetics, although to a modest degree. Heritability estimates, providing a measure of the proportion of variance of a phenotype that could be attributed to genetics, and the sibling relative risk, a measure of familial aggregation of a phenotype, are in agreement with the concordance data. The entanglement of genetic and shared environmental effects confound these measures of familial aggregation. By studying siblings, we attempted to minimize the impact of disparate environmental factors, such as age and duration of infection, gender, and mode of acquisition, that could influence the phenotypes of viral clearance and progression of liver disease. Some portion of the associations observed in the current study probably reflects non-genetic factors that aggregate in the family environment. Nevertheless, the data provided herein would represent a plausible estimate for the upper limit of genetic influence.

The sibling relative risk $\left(\lambda_{\mathrm{s}}\right)$ is an important measure of familial aggregation that is used as a guide to estimate the feasibility of identifying genetic factors $(42,57)$. Ultimately the feasibility of detecting a genetic effect depends on the genotypic relative risk and the frequency of the disease associated allele, neither of which can be reliably estimated from $\mathrm{h}^{2}$ or $\lambda_{\mathrm{s}}(42)$. Simulation has suggested that $\lambda_{\mathrm{s}}>2.3$ suggests but does not guarantee that a disease susceptibility gene locus can be mapped if there are gene-gene or gene-environment interactions (42). As context, $\lambda_{\mathrm{s}}$ for schizophrenia and type 1 diabetes are approximately 9 and 60, respectively (57), suggesting that the genetic dissection of these traits is more likely to be tractable. For the phenotypes studied in siblings with hepatitis $\mathrm{C}$ infection, $\lambda_{\mathrm{s}}$ is relatively small (ranging between 1.6 and 2.1). This suggests that genes with high genotypic relative risk may not exist and that detecting polymorphisms that affect viral clearance and disease progression will require large sample size or analysis, ideally taking into account gene-environment interactions. This information is extremely important when assessing the feasibility of gene mapping studies in this population and serves as a cautionary note for future investigations.

\section{Acknowledgments}

This study was funded in part by RO1 HL 64817-01 (Fried PI), K24 DK06614 (Fried PI), NCI Contract N01CP-01004, and the Intramural Research Program of the National Cancer Institute, NIH. 


\section{References}

1. Alter MJ, Kruszon-Moran D, Nainan OV, McQuillan GM, Gao F, Moyer LA, Kaslow RA, et al. The prevalence of hepatitis C virus infection in the United States, 1988 through 1994. N Engl J Med. 1999; 341:556-562. [PubMed: 10451460]

2. Kenny-Walsh E. Clinical outcomes after hepatitis $\mathrm{C}$ infection from contaminated anti-D immune globulin. Irish Hepatology Research Group. N Engl J Med. 1999; 340:1228-1233. [PubMed: 10210705]

3. Fanning L, Kenny E, Sheehan M, Cannon B, Whelton M, O’Connell J, Collins JK, et al. Viral load and clinicopathological features of chronic hepatitis $\mathrm{C}(1 \mathrm{~b})$ in a homogeneous patient population. Hepatology. 1999; 29:904-907. [PubMed: 10051496]

4. Wiese M, Berr F, Lafrenz M, Porst H, Oesen U. Low frequency of cirrhosis in a hepatitis C (genotype 1b) single-source outbreak in germany: a 20-year multicenter study. Hepatology. 2000; 32:91-96. [PubMed: 10869294]

5. National Institutes of Health Consensus Development Conference Statement: Management of hepatitis C 2002 (June 10-12, 2002). Gastroenterology. 2002; 123:2082-2099. [PubMed: 12454863]

6. Fanning LJ. The Irish paradigm on the natural progression of hepatitis $\mathrm{C}$ virus infection: an investigation in a homogeneous patient population infected with HCV $1 \mathrm{~b}$ (review). Int J Mol Med. 2002; 9:179-184. [PubMed: 11786930]

7. Di Bisceglie AM. Chronic hepatitis $\mathrm{C}$ viral infection in patients with normal serum alanine aminotransferases. Am J Med. 1999; 107:53S-55S. [PubMed: 10653458]

8. Marcellin P, Martinot M, Boyer N, Levy S. Treatment of hepatitis C patients with normal aminotransferases levels. Clin Liver Dis. 1999; 3:843-853. [PubMed: 11291254]

9. Seeff LB, Buskell-Bales Z, Wright EC, Durako SJ, Alter HJ, Iber FL, Hollinger FB, et al. Longterm mortality after transfusion-associated non-A, non-B hepatitis. The National Heart, Lung, and Blood Institute Study Group. N Engl J Med. 1992; 327:1906-1911. [PubMed: 1454085]

10. Forman LM, Lewis JD, Berlin JA, Feldman HI, Lucey MR. The association between hepatitis C infection and survival after orthotopic liver transplantation. Gastroenterology. 2002; 122:889-896. [PubMed: 11910340]

11. Kim WR, Brown RS Jr, Terrault NA, El-Serag H. Burden of liver disease in the United States: summary of a workshop. Hepatology. 2002; 36:227-242. [PubMed: 12085369]

12. Thomas DL, Astemborski J, Rai RM, Anania FA, Schaeffer M, Galai N, Nolt K, et al. The natural history of hepatitis C virus infection: host, viral, and environmental factors. Jama. 2000; 284:450 456. [PubMed: 10904508]

13. Poynard T, Bedossa P, Opolon P. Natural history of liver fibrosis progression in patients with chronic hepatitis C. The OBSVIRC, METAVIR, CLINIVIR, and DOSVIRC groups. Lancet. 1997; 349:825-832. [PubMed: 9121257]

14. Goedert JJ, Eyster ME, Lederman MM, Mandalaki T, De Moerloose P, White GC 2nd, Angiolillo AL, et al. End-stage liver disease in persons with hemophilia and transfusion-associated infections. Blood. 2002; 100:1584-1589. [PubMed: 12176875]

15. Zhang M, Rosenberg PS, Brown DL, Preiss L, Konkle BA, Eyster ME, Goedert JJ. Correlates of spontaneous clearance of hepatitis C virus among people with hemophilia. Blood. 2006; 107:892897. [PubMed: 16204310]

16. Poynard T, Ratziu V, Charlotte F, Goodman Z, McHutchison J, Albrecht J. Rates and risk factors of liver fibrosis progression in patients with chronic hepatitis c. J Hepatol. 2001; 34:730-739. [PubMed: 11434620]

17. Goedert JJ, Hatzakis A, Sherman KE, Eyster ME. Lack of association of hepatitis C virus load and genotype with risk of end-stage liver disease in patients with human immunodeficiency virus coinfection. J Infect Dis. 2001; 184:1202-1205. [PubMed: 11598846]

18. Eyster ME, Diamondstone LS, Lien JM, Ehmann WC, Quan S, Goedert JJ. Natural history of hepatitis $\mathrm{C}$ virus infection in multitransfused hemophiliacs: effect of coinfection with human immunodeficiency virus. The Multicenter Hemophilia Cohort Study. J Acquir Immune Defic Syndr. 1993; 6:602-610. [PubMed: 8098752] 
19. Sulkowski MS, Thomas DL. Hepatitis C in the HIV-Infected Person. Ann Intern Med. 2003; 138:197-207. [PubMed: 12558359]

20. Bataller R, North KE, Brenner DA. Genetic polymorphisms and the progression of liver fibrosis: a critical appraisal. Hepatology. 2003; 37:493-503. [PubMed: 12601343]

21. Hellier S, Frodsham AJ, Hennig BJ, Klenerman P, Knapp S, Ramaley P, Satsangi J, et al. Association of genetic variants of the chemokine receptor CCR5 and its ligands, RANTES and MCP-2, with outcome of HCV infection. Hepatology. 2003; 38:1468-1476. [PubMed: 14647058]

22. Goyal A, Kazim SN, Sakhuja P, Malhotra V, Arora N, Sarin SK. Association of TNF-beta polymorphism with disease severity among patients infected with hepatitis $\mathrm{C}$ virus. J Med Virol. 2004; 72:60-65. [PubMed: 14635012]

23. Muhlbauer M, Bosserhoff AK, Hartmann A, Thasler WE, Weiss TS, Herfarth H, Lock G, et al. A novel MCP-1 gene polymorphism is associated with hepatic MCP-1 expression and severity of HCV-related liver disease. Gastroenterology. 2003; 125:1085-1093. [PubMed: 14517792]

24. Chevillard C, Moukoko CE, Elwali NE, Bream JH, Kouriba B, Argiro L, Rahoud S, et al. IFNgamma polymorphisms (IFN-gamma +2109 and IFN-gamma +3810 ) are associated with severe hepatic fibrosis in human hepatic schistosomiasis (Schistosoma mansoni). J Immunol. 2003; 171:5596-5601. [PubMed: 14607968]

25. Powell EE, Edwards-Smith CJ, Hay JL, Clouston AD, Crawford DH, Shorthouse C, Purdie DM, et al. Host genetic factors influence disease progression in chronic hepatitis C. Hepatology. 2000; 31:828-833. [PubMed: 10733535]

26. Bonkovsky HL, Troy N, McNeal K, Banner BF, Sharma A, Obando J, Mehta S, et al. Iron and HFE or TfR1 mutations as comorbid factors for development and progression of chronic hepatitis C. J Hepatol. 2002; 37:848-854. [PubMed: 12445428]

27. Bataller R, North KE, Brenner DA. Genetic polymorphisms and the progression of liver fibrosis: a critical appraisal. Hepatology. 2003 in press.

28. Lander E, Kruglyak L. Genetic dissection of complex traits: guidelines for interpreting and reporting linkage results. Nat Genet. 1995; 11:241-247. [PubMed: 7581446]

29. Wacholder S, Chanock S, Garcia-Closas M, El Ghormli L, Rothman N. Assessing the probability that a positive report is false: an approach for molecular epidemiology studies. J Natl Cancer Inst. 2004; 96:434-442. [PubMed: 15026468]

30. Wacholder S, Rothman N, Caporaso N. Counterpoint: bias from population stratification is not a major threat to the validity of conclusions from epidemiological studies of common polymorphisms and cancer. Cancer Epidemiol Biomarkers Prev. 2002; 11:513-520. [PubMed: 12050091]

31. Wacholder S, Chatterjee N, Hartge P. Joint effect of genes and environment distorted by selection biases: implications for hospital-based case-control studies. Cancer Epidemiol Biomarkers Prev. 2002; 11:885-889. [PubMed: 12223433]

32. Thomas DC, Witte JS. Point: population stratification: a problem for case-control studies of candidate-gene associations? Cancer Epidemiol Biomarkers Prev. 2002; 11:505-512. [PubMed: 12050090]

33. Fried MW, Peter J, Hoots K, Gaglio PJ, Talbut D, Davis PC, Key NS, et al. Hepatitis C in adults and adolescents with hemophilia: a randomized, controlled trial of interferon alfa- $2 \mathrm{~b}$ and ribavirin. Hepatology. 2002; 36:967-972. [PubMed: 12297845]

34. Fried MW. Management of hepatitis C in the hemophilia patient. Am J Med. 1999; 107:85S-89S. [PubMed: 10653465]

35. Brettler DB, Alter HJ, Dienstag JL, Forsberg AD, Levine PH. Prevalence of hepatitis C virus antibody in a cohort of hemophilia patients. Blood. 1990; 76:254-256. [PubMed: 2114186]

36. Kroner BL, Rosenberg PS, Aledort LM, Alvord WG, Goedert JJ. HIV-1 infection incidence among persons with hemophilia in the United States and western Europe, 1978-1990. Multicenter Hemophilia Cohort Study. J Acquir Immune Defic Syndr. 1994; 7:279-286. [PubMed: 8106967]

37. Goedert JJ, Kessler CM, Aledort LM, Biggar RJ, Andes WA, White GC 2nd, Drummond JE, et al. A prospective study of human immunodeficiency virus type 1 infection and the development of AIDS in subjects with hemophilia. N Engl J Med. 1989; 321:1141-1148. [PubMed: 2477702] 
38. Goedert JJ. Prevalence of conditions associated with human immunodeficiency and hepatitis virus infections among persons with hemophilia, 2001-2003. Haemophilia. 2005 in press.

39. Kroner BL, Goedert JJ, Blattner WA, Wilson SE, Carrington MN, Mann DL. Concordance of human leukocyte antigen haplotype-sharing, CD4 decline and AIDS in hemophilic siblings. Multicenter Hemophilia Cohort and Hemophilia Growth and Development Studies. Aids. 1995; 9:275-280. [PubMed: 7755916]

40. Strachan, T.; Read, AP. Human Molecular Genetics 2. New York, NY: Wiley and Sons; 1999.

41. Almasy L, Blangero J. Multipoint quantitative-trait linkage analysis in general pedigrees. Am J Hum Genet. 1998; 62:1198-1211. [PubMed: 9545414]

42. Rybicki BA, Elston RC. The relationship between the sibling recurrence-risk ratio and genotype relative risk. Am J Hum Genet. 2000; 66:593-604. [PubMed: 10677319]

43. Vogt M, Lang T, Frosner G, Klingler C, Sendl AF, Zeller A, Wiebecke B, et al. Prevalence and clinical outcome of hepatitis $\mathrm{C}$ infection in children who underwent cardiac surgery before the implementation of blood-donor screening. N Engl J Med. 1999; 341:866-870. [PubMed: 10498458]

44. Lai ME, Mazzoleni AP, Argiolu F, De Virgilis S, Balestrieri A, Purcell RH, Cao A, et al. Hepatitis $\mathrm{C}$ virus in multiple episodes of acute hepatitis in polytransfused thalassaemic children. Lancet. 1994; 343:388-390. [PubMed: 7905553]

45. Khakoo SI, Thio CL, Martin MP, Brooks CR, Gao X, Astemborski J, Cheng J, et al. HLA and NK cell inhibitory receptor genes in resolving hepatitis C virus infection. Science. 2004; 305:872-874. [PubMed: 15297676]

46. Oleksyk TK, Thio CL, Truelove AL, Goedert JJ, Donfield SM, Kirk GD, Thomas DL, et al. Single nucleotide polymorphisms and haplotypes in the IL10 region associated with HCV clearance. Genes Immun. 2005

47. Thio CL, Goedert JJ, Mosbruger T, Vlahov D, Strathdee SA, O’Brien SJ, Astemborski J, et al. An analysis of tumor necrosis factor alpha gene polymorphisms and haplotypes with natural clearance of hepatitis C virus infection. Genes Immun. 2004; 5:294-300. [PubMed: 15071492]

48. Thio CL, Gao X, Goedert JJ, Vlahov D, Nelson KE, Hilgartner MW, O’Brien SJ, et al. HLACw*04 and hepatitis C virus persistence. J Virol. 2002; 76:4792-4797. [PubMed: 11967296]

49. Knapp S, Yee LJ, Frodsham AJ, Hennig BJ, Hellier S, Zhang L, Wright M, et al. Polymorphisms in interferon-induced genes and the outcome of hepatitis $\mathrm{C}$ virus infection: roles of MxA, OAS-1 and PKR. Genes Immun. 2003; 4:411-419. [PubMed: 12944978]

50. Chen L, Borozan I, Feld J, Sun J, Tannis LL, Coltescu C, Heathcote J, et al. Hepatic gene expression discriminates responders and nonresponders in treatment of chronic hepatitis $\mathrm{C}$ viral infection. Gastroenterology. 2005; 128:1437-1444. [PubMed: 15887125]

51. Houldsworth A, Metzner M, Rossol S, Shaw S, Kaminski E, Demaine AG, Cramp ME. Polymorphisms in the IL-12B gene and outcome of HCV infection. J Interferon Cytokine Res. 2005; 25:271-276. [PubMed: 15871664]

52. Naito M, Matsui A, Inao M, Nagoshi S, Nagano M, Ito N, Egashira T, et al. SNPs in the promoter region of the osteopontin gene as a marker predicting the efficacy of interferon-based therapies in patients with chronic hepatitis C. J Gastroenterol. 2005; 40:381-388. [PubMed: 15868370]

53. Matsuyama N, Mishiro S, Sugimoto M, Furuichi Y, Hashimoto M, Hijikata M, Ohta Y. The dinucleotide microsatellite polymorphism of the IFNAR1 gene promoter correlates with responsiveness of hepatitis C patients to interferon. Hepatol Res. 2003; 25:221-225. [PubMed: 12697242]

54. Promrat K, McDermott DH, Gonzalez CM, Kleiner DE, Koziol DE, Lessie M, Merrell M, et al. Associations of chemokine system polymorphisms with clinical outcomes and treatment responses of chronic hepatitis C. Gastroenterology. 2003; 124:352-360. [PubMed: 12557141]

55. Luo S, Cassidy W, Jeffers L, Reddy KR, Bruno C, Howell CD. Interferon-stimulated gene expression in black and white hepatitis $\mathrm{C}$ patients during peginterferon alfa-2a combination therapy. Clin Gastroenterol Hepatol. 2005; 3:499-506. [PubMed: 15880320]

56. Theodore D, Fried MW, Kleiner DE, Kroner BL, Goedert JJ, Eyster ME, Faust SP, et al. Liver biopsy in patients with inherited disorders of coagulation and chronic hepatitis C. Haemophilia. 2004; 10:413-421. [PubMed: 15357765] 
57. Merikangas KR, Risch N. Genomic priorities and public health. Science. 2003; 302:599-601. [PubMed: 14576422] 
Table 1

Demographic characteristics of all hemophiliacs and hemophilic siblings with hepatitis $\mathrm{C}$ infection

\begin{tabular}{|l|c|c|c|}
\hline Characteristic & Total Hemophilic Population (n=3993) & Subset of Siblings (n=514) & p value \\
\hline Hemophilia type & & & \\
\hline A & $3112(78.3 \%)$ & $426(82.9 \%)$ & \\
\hline B & $617(15.5 \%)$ & $66(12.9 \%)$ & $\mathrm{p}=0.04$ \\
\hline Other & $247(6.2 \%)$ & $22(4.2 \%)$ & \\
\hline Severity of hemophilia & & & \\
\hline Mild & $706(17.7 \%)$ & $67(13 \%)$ & \\
\hline Moderate & $607(15.3 \%)$ & $72(14 \%)$ & $\mathrm{p}=0.01$ \\
\hline Severe & $1663(67.0 \%)$ & $375(73 \%)$ & \\
\hline Age at HCV infection & & & \\
\hline Median & 7.5 years & 7.5 years & \\
\hline HIV status & & & $\mathrm{p}=0.002$ \\
\hline HIV + & $1815(45.5 \%)$ & $278(54.1 \%)$ & \\
\hline HIV - & $2177(54.5 \%)$ & $236(45.9 \%)$ & $\mathrm{ns}$ \\
\hline HBsAg + & $234(6.6 \%)$ & $35(7.4 \%)$ & \\
\hline Alcohol usage (weekly) & & & \\
\hline None & $1761(51.2 \%)$ & $239(52.5 \%)$ & \\
\hline$<8$ drink/week & $1302(37.8 \%)$ & $160(35.1 \%)$ & \\
\hline $8-14$ drinks/week & $235(6.8 \%)$ & $34(7.5 \%)$ & \\
\hline$>14$ drinks/week & $144(4.2 \%)$ & & \\
\hline HCV RNA status & & & \\
\hline HCV RNA + & $204(6.2 \%)$ & & \\
\hline HCV RNA - (spontaneous) & & & \\
\hline HCV RNA - (treated) & & & \\
\hline & & & \\
\hline
\end{tabular}


Table 2

Expected and observed concordance rates for viral clearance and advanced liver disease within hemophilic sibships.

\begin{tabular}{|l|c|c|c|}
\hline & Expected & Observed in sib pairs & $\mathbf{p}$ value \\
\hline Spontaneous HCV clearance (Total population) & $2.7 \%$ & $4.0 \%$ & $\mathrm{p}=0.07$ \\
\hline Spontaneous HCV clearance (HIV-negative) & $4.3 \%$ & $8.8 \%$ & $\mathrm{p}=0.04$ \\
\hline Treatment-related HCV clearance & $13.3 \%$ & $31.3 \%$ & $\mathrm{p}=\mathrm{ns}$ \\
\hline
\end{tabular}


Table 3

Heritability and sibling relative risk for spontaneous and treatment-induced viral clearance and for the development of advanced liver disease in hemophiliacs with hepatitis $\mathrm{C}$ infection.

\begin{tabular}{|l|c|c|c|}
\hline & Heritability $\left(\mathbf{h}^{\mathbf{2}}\right)$ & $\mathbf{P}$ value & Sibling Relative Risk $(\lambda \mathbf{s})$ \\
\hline Spontaneous viral clearance & $0.25 \pm 0.14$ & $\mathrm{P}=0.04$ & 1.6 \\
\hline Treatment-induced viral clearance & $0.43 \pm 0.42$ & $\mathrm{p}=0.10$ & 1.7 \\
\hline Advanced liver disease & $0.29 \pm 0.13$ & $\mathrm{P}=0.02$ & 2.1 \\
\hline
\end{tabular}


Table 4

Clinical and laboratory features of advanced liver disease.

\begin{tabular}{|l|c|c|c|}
\hline Characteristic & Total Hemophilic Population (n=2238) & Subset of Hemophilia Siblings (n=250) & p value \\
\hline Encephalopathy & $38(1.7 \%)$ & $7(2.8 \%)$ & $\mathrm{ns}$ \\
\hline Ascites & $128(5.7 \%)$ & $19(7.6 \%)$ & $\mathrm{ns}$ \\
\hline Esophageal varices & $68(3.0 \%)$ & $4(1.6 \%)$ & $\mathrm{ns}$ \\
\hline Bridging fibrosis or cirrhosis on biopsy & $31(24 \%)$ & $3(23 \%)$ & $\mathrm{ns}$ \\
\hline Liver cancer & 9 & 0 & $\mathrm{~ns}$ \\
\hline Liver death & $105(4.7 \%)$ & $13(5.2 \%)$ & $\mathrm{ns}$ \\
\hline Hypoalbuminemia & $103(7.9 \%)$ & $16(10.4 \%)$ & $\mathrm{ns}$ \\
\hline Thrombocytopenia & $262(11.7 \%)$ & $28(11.2 \%)$ & $\mathrm{ns}$ \\
\hline Bilirubin $>$ & $85(5.7 \%)$ & $12(7.1 \%)$ & $\mathrm{ns}$ \\
\hline Prolonged prothrombin time & $118(11 \%)$ & $18(13 \%)$ & $\mathrm{ns}$ \\
\hline Cirrhosis & $57(2.6 \%)$ & $5(2.0 \%)$ & $\mathrm{ns}$ \\
\hline Platelets < $100,000 \mathrm{c} / \mathrm{mm}^{3}$ & $146(6.5 \%)$ & $13(5.2 \%)$ & $\mathrm{ns}$ \\
\hline
\end{tabular}

